\title{
Introduction: Changing Perspectives in Business and Development
}

\author{
Elise Wach and Jodie Thorpe
}

\begin{abstract}
While development debates have largely shifted away from the polarised view of 'state versus market', significant divergences in understandings and approaches remain about the roles and potentials of business, state and society actors. Underlying these differences are often implicit assumptions about the nature of markets themselves. This introduction first provides an overview of current broad lines of debate and their implications and then goes on to discuss the ways in which the articles in this IDS Bulletin provide more nuanced insights about the new actors, relationships and approaches. With questions remaining about the ability of business and market-focused initiatives to impact on social, environmental and economic aspects of development, the articles in this IDS Bulletin point to the need for approaches which are nuanced, experimental, bottom up and inclusive of multiple perspectives.
\end{abstract}

\section{The market or the state?}

The debate on the role of business and markets in development has a long history, marked by divergent and often strongly held perspectives, but also relatively rapid shifts in dominant thinking about what is feasible and desirable. While only two decades ago debates were framed in terms of the state versus the market (Colclough and Manor 1993), there is currently broad consensus that both are essential, although perspectives diverge on the appropriate roles of each. The articles in this special issue of the IDS Bulletin aim to reflect some of the shifting understandings of the roles of business, markets and the state in development.

One prevalent view has emphasised economic growth as the pathway to development and poverty reduction. The UK Secretary of State for International Development, Justine Greening, in her 2013 speech on business and development at the London Stock Exchange, summed it up as reducing overall barriers to trade and investment, unlocking the ability of entrepreneurs and business people to drive economic growth, and encouraging greater investment by business. ${ }^{1}$ This view is underpinned by a notion of the private sector as efficient and entrepreneurial - taking risks and reaping rewards while providing necessary products and services and creating jobs in the process. The role of governments is understood to be providing basic infrastructure, creating a predictable investment climate and protecting property rights while abstaining from picking winners or otherwise meddling in the economy (Moore and Schmitz 2008). This approach has focused primarily on 'quantity': more (i.e. jobs, growth, wealth) is better. Countries are making extensive efforts to 'upgrade' manufacturing and agricultural sectors in developing countries to improve competitiveness and increase value (Gereffi et al. 2001). This includes, for example, attempts to grow the garments industry in countries such as Bangladesh, Vietnam and more recently in Myanmar (Burma).

The role of the state in this perspective is 'market fixing'. The premise being that, at least in mainstream economics, markets are inherently efficient, but 'market failures' (for example transaction costs, coordination failures, imperfect competition, imperfect information) undermine this efficiency (Mazzucato and Penna 2014, drawing on Fama 1970). The role of the state is to correct market failures, in order to make it easier for entrepreneurs to invest, create growth, employ people and produce needed goods and services. The growth-focused approach to development is often implicitly premised on this idea of market efficiency. 
Another perspective sees business as part of the problem as private interests and the public good often diverge. Although growth is necessary, it is insufficient on its own as it misses crucial issues of the 'quality' of economic activity, such as job safety, living wages, transparent procurement practices, health outcomes and environmental sustainability. This view is underpinned by a notion of business as rapacious and exploitative, with business activities imposing social costs that are not reflected in the costs facing the business itself. Pollution is the most obvious case in point. Conflicts between business interests and individual or public welfare are increasingly recognised in, for example, the food and beverage (Brownell and Horgen 2004) and pharmaceutical industries (Brezis 2008). Powerful businesses are also seen to distort markets, with the returns to monopolistic or oligopolistic firms inflated, while the welfare of other businesses, labour and/or consumers is reduced (Humphrey et al. 2014). The increased understanding and focus on rising levels of inequality in countries around the globe has also highlighted the problem of wealth concentration (Piketty 2014), leading to further questions as to whether 'more business' is the solution. Individuals participate in markets on very unequal terms, and benefits or harms are allocated in ways that often favour those that are already advantaged.

In this perspective, the state or other non-business actors such as civil society or non-profit organisations have a more active role, though perhaps somewhat 'defensive' in nature (for example defending rights, the environment, marginalised populations, etc.). State regulation is needed to curb the worst corporate abuses, for example through ensuring that firms pay a minimum wage and the environment is protected to a certain extent. If businesses are made to pay their taxes, states can spend the money on the things that matter for development - particularly, though not exclusively, health and education. Thus, through a welfare state and progressive taxation, states can counter inequality that might otherwise grow without their actions. Such efforts to regulate and to tax businesses could be interpreted to be based on the 'market-fixing' approach, although with a slightly heavier hand than in the first perspective.

\section{Inclusive market systems}

Going beyond the perspective of businesses as inherently part of the solution or the root of the problem, a number of development actors (state and non-state) are exploring ways to support or leverage the private sector to bring about positive economic, social and environmental outcomes - a more 'inclusive' version of 'more is better'. A range of development actors (bilateral and multilateral agencies, governments and non-governmental organisations (NGOs)) have engaged with businesses in a variety of ways, such as through public-private partnerships (for example, the United States Agency for International Development (USAID)), collaborations with large businesses to help develop (profitable) business models that are more 'inclusive' of the 'base of the pyramid' (for example, the International Finance Corporation), value chain development initiatives (for example, the German Federal Enterprise for International Cooperation (GIZ)) and most recently, market systems approaches (for example, the Department for International Development (DFID)). Through these approaches, companies and development actors seek to benefit poor and marginalised populations by modifying businesses' operations to increase access to goods and services ('the poor as consumers'), access to end markets ('the poor as producers' or 'entrepreneurs') and access to and/or improved quality of jobs ('the poor as employees'). For some development actors, such collaborative and private sector-supportive approaches have occurred simultaneously with activities which maintain a critical view of business (for example, Oxfam's 'Behind the Brands' campaign). ${ }^{2}$

In most cases, such inclusive business collaborations have occurred on a case-by-case basis where an alignment of objectives between businesses (usually large companies) and development actors seems feasible. However, there has been growing recognition that collaboration with individual businesses or support to specific value chains alone are unlikely to address development problems, particularly not at scale. Thus there has also been a rise in multistakeholder initiatives (for example, the Roundtable on Sustainable Palm Oil, Ethical Trading Initiative) and global alliances (for example, the Global Alliance for Improved Nutrition (GAIN)) with a broader remit. The rise of market-centred approaches such as Making Markets Work for the Poor (M4P) and Market System Development is also testament to the growing recognition that collaboration with individual businesses alone is insufficient. The goal 
of such initiatives is to achieve long-lasting change in 'market systems' in order to achieve large-scale development impacts (Springfield Centre 2008).

Among those supporting market systems and inclusive business approaches are a diversity of perspectives about the nature of markets and therefore the appropriate roles of state and non-state actors. While many interventions reflect implicit assumptions about market efficiency and the role of interventions as 'market fixing', some initiatives could be perceived as following a 'market-shaping' theory, in which a state or non-state development actor plays an essential role in creating and shaping markets themselves, not just fixing their 'imperfections' (Polanyi 1944). Further, there has been a return to conceptions of the market comprising interactions between business and state actors (i.e. that the market in many cases includes the state). This shifts the role of the state from one of 'market fixing' to that of 'market shaping' (Mazzucato and Penna 2014). Mazzucato (2013) argues that even in the USA, the supposed paragon of 'free markets', the state has taken an active role in 'shaping' and even 'creating' markets. She demonstrates that key innovations in information technology (IT), biotechnology and nanotechnology resulted from active state risk-taking that the private sector would be unwilling or incapable of undertaking. Mazzucato and Penna (2014) also argue that the movement of private finance towards speculation and away from investments in the 'real economy', goes beyond a market failure to represent an inherently flawed system; one in which state investment banks are needed in order to 'shape' or even 'create' markets for economic development.

It is against this backdrop that we commissioned this special issue of the IDS Bulletin on business, state and society in development, with the aim of reorienting the debate towards a deeper analysis of business- and market-led approaches, and an exploration of the roles of business, state and society in development. The articles in this IDS Bulletin assess the conditions under which new relationships between business and development actors are likely to be effective in addressing key constraints to development, and where the challenges lie. They explore how transformations towards new systems that achieve goals of economic prosperity, environmental sustainability and human wellbeing may take place. They also raise some questions about what the end goal of business and development is, and whether our current goals are 'fit for purpose'.

\section{New actors and relationships}

The potential role of new actors and unusual coalitions in driving change features strongly in the articles in this IDS Bulletin. Chaturvedi, Arora and Singh Saluja start this special issue with an analysis of how traditional informal models of urban waste management in India are under pressure because they fail to solve the waste management crisis, paving the way for formal company participation in the sector. Actors with convening power, such as the local government, can play a pivotal role in designing public-private partnerships (PPPs) that encourage collaboration between the traditional and formal private sector actors. However, the case of Delhi identifies a narrow government focus on large private sector actors and the formation of interest and opportunity-based adversarial alliances and conflict as a result. The alternative proposed is a 'deliberative PPP' - with maximum public debate about the purpose and inclusivity of collaboration between state, civil and market actors, as well as achieving the economic purposes of collaboration.

Sarwar explores new partnerships between the government and non-state actors for health market innovation in Bangladesh. He finds that the synergy of incentives of these partners is a key determinant of partnership success, and that effective partnerships may arise with a wide range of actors (for example, from the information and communications technology (ICT) or retail sectors) that go beyond the narrowly defined 'health market system'. Collaborations across sectors may not only be effective but they may also be (relatively) easy to achieve, given the absence of competitive pressures. Like Chaturvedi et al., the role of third parties - governments, NGOs or international organisations (for example, GAIN) is highlighted. However, Sarwar also points to challenges that the need for this third party creates for the long-term sustainability of the model - and the risk of innovations losing a propoor focus when the third party exits.

Borrella, Mataix and Carrasco-Gallego highlight an example of how demand-driven shifts in the coffee market have resulted in benefits for small coffee producers. They illustrate how the process 
of decommoditisation has created a higher value market for small producers, which they are able to access through 'connective businesses'. These connective businesses reduce transactional and productivity constraints (including through offering training), connecting farmers with coffee roasters that they might otherwise not be able to access or work with. Borella $e t$ al. find that the relationship between connective businesses and smallholder farmers is mutually beneficial. In mitigating risks, contracts are deemed to be important, but mutual commitment and trust even more so. However, in discussing scale, they note that the speciality coffee market makes up only 10 per cent of world consumption. Therefore, efforts to integrate vulnerable farmers into differentiated market segments should not come at the expense of attempting to improve the mainstream.

New relationships at the multilateral level are reviewed by Fortin and Jolly who assess the last 15 years of United Nations' efforts to codify UN policies vis-à-vis business and to mobilise the skills and resources of companies towards inclusive globalisation. They identify five new modes of UN-business relationship from engaging the cooperation of business through initiatives such as the United Nations Global Compact, to developing value-oriented norms and standards through the UN Guiding Principles on Business and Human Rights. While acknowledging the difficulties in evaluating the achievements of these efforts, given the complex variables involved, they find that progress has been achieved and identify network learning processes (such as the Global Compact) as being promising. However, what needs to not be forgotten in exploiting the potential of these new relationships is that these are not just technical, problem-solving processes - the potential for conflicts of interest between governments and business has not disappeared. This calls for political debate and decision-making in the appropriate intergovernmental UN bodies.

\section{Beyond business to markets}

A number of the articles together act as a cautionary tale against the assumption that working with business translates to significant development impact, particularly for marginalised populations. Humphrey and Robinson illustrate the limitations of working with individual businesses or promoting certain products as a means of reducing chronic malnutrition. The constraints that businesses face in developing distribution and marketing systems to deliver micronutrient-rich food to this population are substantial. Perhaps more importantly, these populations are already served by (largely informal) markets. Rather than assuming that formal value chains will eventually replace the informal sector, they argue that development actors need to work through the existing markets in which these populations source their food. They also make the case that there is a clear need to frame food market interventions as both market systems interventions and as interventions in complex policy systems.

In her article analysing the extent to which nine pro-poor business programmes are designed to achieve systemic change, Thorpe also finds limits in the potential of approaches led by individual businesses. Even where positive impacts on poverty may be achieved, company-led initiatives are likely to be limited to those producers, consumers or employees within the value chain, and dependency may be created where benefits cannot be sustained without the continued involvement of the company. Approaches that create new enterprises or platforms of actors are more likely to understand challenges and develop solutions that are systemic and sustainable in the long term, beyond the involvement of any one actor. Even with these more systemic approaches, however, there are different and potentially conflicting interests. Yet questions of power, such as the negotiating power between companies and smallholders, or questions of who governs collective organisations such as cooperatives are weakly addressed, with implications for poverty and equity outcomes. Thorpe concludes with implications for development actors working with business.

\section{What are the impacts and what is the end goal?}

The articles in this IDS Bulletin also remind us that 'development' and 'benefit' have different interpretations, replicating some of the longstanding debates and fault lines in development. Drawing on complex systems theories and their own experiences with private sector initiatives, Jenal and Cunningham argue that 'solutions' or even fixed goals and targets cannot be preconceived in advance, from the top down. They propose new approaches which aim to mitigate the extent to which our implicit 
'theories of change' (influenced by our values and worldviews) limit or bias the changes we want to see and the pathways by which they can be achieved. They propose that projects should be guided by a broad 'strategic intent' that is general enough to allow for a flexible portfolio of interventions that can both be adapted over time and can also go beyond the private sector and markets to address governance, institutional or other issues. In order to determine which interventions are needed and will be successful, they suggest an exploratory phase in which a wide range of potential strategies can be tested in order to maintain as much diversity as possible in hypotheses about how change could happen. Interventions would then be selected to be 'scaled up', based on signs of likely success, rather than based on the implicit assumptions of a small group of people.

Finally, in the context of the global economic crisis, Trebeck explores the scope to rethink the 'end goals' of business and of society - going beyond incremental increases in gross domestic product (GDP) and systems based on profit and accumulation towards the quality of growth, environmental sustainability, living well and sharing benefits. Business has an important role in this 'new economic paradigm' as a facilitator, enhancer and deliverer (and blocker) of this change. She sees evidence that elements of this paradigm are emerging, from the circular and sharing economy movement to the emergence of new organisational forms which pursue a range of goals beyond short-term profit. The state has a role in galvanising the most effective contribution of business, such as by inculcating new horizons and incentives, through widened goals, and by reconstituting business, through changes to company law.

\section{Questions remain}

The picture that emerges from the collection of articles in this IDS Bulletin special issue on business, state and society in development is of increasingly nuanced collaborations and partnerships: business-state, business-society, and between formal and informal business. They have arisen in response to new (often global) challenges in an increasingly complex and interconnected world, to which neither the previous state-centred nor market-centred approaches are well equipped to respond. There is also increasing recognition of the dynamic interrelationships between business, state and society, and between these actors and the markets, institutions, rules and norms that surround them.

Yet for all the advances in knowledge and understanding of how business, markets and states interact in development, a number of fundamental questions remain. None of the articles has pointed to really clear evidence of the positive impact of these new business and development initiatives on poverty. For example, Borella et al. identify the potential for positive outcomes but also the need for research to assess the actual poverty or wider development impacts of connecting smallholder coffee farmers with niche coffee markets. Similarly, a lack of data left Sarwar unable to comment on the real changes in health or wellbeing driven by health market innovations in Bangladesh. Humphrey and Robinson explicitly highlight the fact that nutritional business models do not reach the poorest. As partnership-based and systems-led approaches have proliferated and become more complicated, and understanding impacts becomes more challenging, the focus of inquiry has increasingly been on what it takes for these new approaches to work at all, rather than what it takes to make them work for development.

Based on available evidence, there seems to be real limitations to what the market is delivering in terms of solutions to poverty and inequality. Even if markets can be made to benefit the 'well-off' poor, what of the poorest? The response seems to be that we should go as far as possible with the market and let the state take care of the rest. However, further work is needed to understand whether increasing government engagement in public-private partnerships or market-shaping activities is sufficiently complemented by attention to state-delivered services such as social protection.

What the articles do collectively make clear is that as businesses assume or are given a greater role in areas previously dominated by state or society actors, often bringing important and useful perspectives, they also have the scope to influence policy development in new and potentially more fundamental ways. Putting aside direct attempts by business to influence policy, when companies engage in policy processes, they come with implicit assumptions - and often strategies - that influence how public challenges and solutions are framed. Governments and 
NGOs do the same. It is important to understand how narratives develop, what influences and perpetuates them, and how they impact what change is considered feasible and desirable.

Finally, the implicit assumption which lies behind the growth of interest in business and development is that interventions that are led by business or that work through markets will be self-sustaining and lead to significant impacts for large numbers of people. Yet again, the evidence is weak. Pilot projects, niche innovations and substantial subsidies feature in several of the articles. The 'business case' or market drivers for initiatives that reduce poverty and inequality in a systemic way are, in most cases, rather weak.

\section{Notes}

1 www.gov.uk/government/speeches/investingin-growth-how-dfid-works-in-new-andemerging-markets.

2 www.behindthebrands.org.

\section{References}

Brezis, M. (2008) 'Big Pharma and Health Care: Unsolvable Conflict of Interests Between Private Enterprise and Public Health', Israel Journal of Psychiatry and Related Sciences 48.2: 83-9

Brownell, K. and Horgen, K. (2004) Food Fight: The Inside Story of the Food Industry, America's Obesity Crisis and What We Can Do About It, Chicago IL: Contemporary Books

Colclough, C. and Manor, J. (eds) (1993) States or Markets? Neo-liberalism and the Development Policy Debate, Oxford: Oxford University Press

Gereffi, G.; Humphrey, J.; Kaplinsky, R. and Sturgeon, T.J. (2001) 'Introduction: Globalisation, Value Chains and Development', IDS Bulletin 32.3: 1-8

Humphrey, J.; Spratt, S.; Thorpe, J. and Henson, S. (2014) Understanding and Enhancing the Role of Business in International Development: A Conceptual Framework and Agenda for Research, IDS Working Paper 440, Brighton: IDS

Mazzucato, M. (2013) The Entrepreneurial State: Debunking Public vs Private Sector Myths, London: Anthem Press
This does not lead us to conclude that working with or through business and markets are incompatible or unhelpful approaches to development. Markets affect the lives of most communities - rich and poor - and they can be made to work better and more equitably. However, business and markets do not represent a 'silver bullet' for development. The articles in this IDS Bulletin point to the need for approaches that are nuanced, experimental, bottom up and inclusive of multiple perspectives. More attention is required in relation to the ways in which changes in business practices and market dynamics impact on poverty, inequality and environmental sustainability.

Mazzucato, M. and Penna, C. (2014) Beyond Market Failures: The Market Creating and Shaping Roles of State Investment Banks, SPRU Working Paper Series 21, Brighton: University of Sussex

Moore, M. and Schmitz, H. (2008) Idealism, Realism and the Investment Climate in Developing Countries, IDS Working Paper 307, Brighton: IDS

Piketty, T. (2014) (trans. Arthur Goldhammer) Capital in the Twenty-First Century, Harvard: Harvard University Press

Polanyi, K. (1944) The Great Transformation: The Political and Economic Origins of Our Time, Boston MA: Beacon Press

Springfield Centre for Business in Development (2008) A Synthesis of the Making Markets Work for the Poor Approach, www.value-chains.org/dyn/ bds/docs/681/Synthesis_2008.pdf (accessed 13 April 2015) 